\title{
Mortuary Technicians
}

SIR,-Perhaps the Brodrick Committee can tell us where the mortuary technicians are coming from to cope with the envisaged increased number of necropsies (20 November, pp. 441 and 498)?-I am, etc.,

C. F. Ross

Group Laboratory,

St. Peter's Hospital,

Chertsey, Surrey

\section{Death in Hospital}

SIR,-Dr. B. Taylor's complaint (27 November, p. 562) of tardy information from hospital concerning notification of the death of one's patient there has been a sore point for years.

Long ago I received a letter about the death of a very old gentleman who had died from pneumonia three months previously in hospital. An undeleted line at the end stated: "We are now leaving him in your care."-I am, etc.,

Keswick, Cumberland

G. J. Phillips

\section{Unusual Complications of Primary Atypical}

\section{Pneumonia due to $M$. pneumoniae}

SIR,-We wish to report a case of primary atypical pneumonia due to Mycoplasma pneumoniae, unusual in that it was complicated by haemorrhagic pleural effusion, overt haemolytic anaemia, and myocarditis.

A 30-year-old white female presented with a two-week history of non-productive cough, rigors, extreme lethargy, anorexia, frontal headache, epistaxis, and transient bilateral earache. A temperature of $102^{\circ} \mathrm{F}\left(38.9^{\circ} \mathrm{C}\right)$ was accompanied by a tachycardia of 110 / min. On the right side of her chest there were clinical and radiological signs of pulmonary consolidation with pleural effusion. The E.S.R. was $108 \mathrm{~mm} / \mathrm{hr}$. (Westergren); W.B.C. 7,300/ $\mathrm{mm}^{3} \quad(62 \%$ neutrophils, $36 \%$ lymphocytes, $2 \%$ monocytes).

In ten days her haemoglobin fell from $12.6 \mathrm{~g} / 100 \mathrm{ml}$ to $8.9 \mathrm{~g} / 100 \mathrm{ml}$. The direct Coombs test was strongly positive, the reticulocyte count was $12 \%$, and the total serum bilirubin $2.0 \mathrm{mg} / 100 \mathrm{ml}$. Serum cold agglutinins were present 1 in 1024 at $4^{\circ} \mathrm{C}$ The Paul-Bunnell test was negative. The Mycoplasma pneumoniae complement fixation titre rose from 1 in 80 to 1 in 640 in 25 days. Complement fixation tests against adenovirus, $C$. burneti, cytomegalovirus, Herpes simplex, influenza $\mathrm{A}$ and $\mathrm{B}$, measles, mumps, respiratory syncytial virus, and psittacosis, were negative except in the case of Varicella zoster against which a titre of 1 in $\mathbf{8 0}$ was obtained on three occasions.

Bacteriological culture of sputum gave a mixed growth of $H$. influenzae and $H$ parainfluenzae. Pleural aspiration yielded sterile blood-stained amber coloured fluid with a protein content of $3.5 \mathrm{~g} / 100 \mathrm{ml}$ Films stained by Giemsa showed numerous red cells with a few polymorphs and plasma cells in a predominantly lymphocytic exudate. There were also numerous macrophages and clumps of desquamated pleomorphic mesothelial cells showing marked hyperplastic changes but no evidence of malignancy. These were characteristic of a resolving inflammatory process. Acid-alcohol- fast bacilli were neither seen in, nor isolated from, sputum or pleural fluid by culture or guinea pig inoculation after eight weeks.

On the third day after admission electrocardiography showed $T$ wave inversion in leads III and A.V.F. On the eleventh day examination showed first degree heart block with a P-R interval of $0.25 \mathrm{sec}$. The $\mathrm{T}$ wave, which had become flattened in A.V.F. remained inverted in lead III.

Treatment with oral tetracycline $2 \mathrm{~g} /$ day was started five days after admission. Within 24 hours the patient became afebrile. Treatment was continued for three weeks. No specific treatment was given for the anaemia.

On discharge three weeks after admission the patient felt much better, the E.S.R. had fallen to $10 \mathrm{~mm}$ in 1 hour, and the reticulocytes to $1 \%$, while the haemoglobin had risen to $15 \mathrm{~g} / 100 \mathrm{ml}$. Radiological and electrocardiographic appearances were normal.

We are indebted to Dr. Cecil Symons for permission to record this note.

-We are, etc.,

Özgen FeIzi ChandRa GRUBB JOYCE I. SKINNER Maria Constantinidou W. G. HENDERSON

Royal Free Hospital,

London W.C.1

\section{Outpatient Termination of Pregnancy}

SIR,- In the interesting and important article by Dr. Stella C. Lewis and others (4 December, p. 606) there is one matter which needs elucidation-the dosage of lignocaine used. It is said that the injection was " $12 \mathrm{ml}$ of $1 \%$ lignocaine (Xylocaine) into the substance of the cervix at the 12,4 , and 8 o'clock positions." Presumably this means a total of $12 \mathrm{ml}$ distributed between the three positions. If, however, it means that $12 \mathrm{ml}$ of $1 \%$ lignocaine was injected in each of three positions, then the usually recommended maximum safe dose of $200 \mathrm{mg}$ of the drug will have been considerably exceeded, and a bulky volume used in vascular areas.

Lignocaine has proved to be a revolutionary advance in local analgesia, but the complications following its too free use in its early days made us aware of its potential toxicity which must be borne in mind, especially when we deal with pregnant patients.-I am, etc.,

Chichester, Sussex

** We have shown Mr. Williams's letter to Dr. Stella Lewis and her colleagues and they inform us that the total dose of lignocaine used was $12 \mathrm{ml}$.-ED., B.M.7.

\section{The Dancing Arrow}

SIR,-To the many well known irritating mannerisms and habits of lecturers a relatively new and deadly one is rapidly spreading.

I refer to the torch that projects an arrow on to the screen. Handled quietly and steadily it is excellent, but more often it dances all over the place, dashes off one corner only to reappear elsewhere, back and forth with great rapidity to underline, round and round to encircle, leaving the audience dizzy and exhausted. At a recent conference it was at its worst.

May I therefore make a plea for the retention of the old-fashioned pointer, which is perfectly adequate on most occasions and so much more restful to the audience.-I am, etc.,

Hatfield, Herts

G. R. Royston

\section{Employment Medical Advisory Service Bill}

SIR,-In spite of a lapse of time there appears to have been no attempt at reconsideration of the Employment Medical Advisory Service Bill. The Bill falls into two sections-the appointed factory doctor service for young people and a new occupational health service-and these should be dealt with separately. No assessment has been made of the present situation. Why has the appointed factory doctor service failed? Inadequacy of staff in numbers and training? Inadequate supervision and foresight?

The appointed factory doctor service is staffed by general practitioners on a parttime basis instructed to do the most superficial and cursory examinations for physical or mental defect. There has been totally inadequate supervision by the Inspectorate of Factories and unique opportunities have been ignored. Suggestions for training and supervision have been disregarded.

At a meeting of the Society of Occupational Medicine and at a Royal Society of Medicine symposium I heard the C.M.O. (Inspectorate of Factories) declare "neither in principle nor detail had the examination altered since inception," and should be abolished-surely a damning indictment of departmental failure.

There are serious objections to the creation of an embryo occupational health service on the slender grounds advanced and on such evident lack of preparation, and to putting it in the hands of those who so lamentably failed to operate the old service efficiently. At the same time it is quite wrong to associate two very different aims and, under cover of developing something new, effectively to abandon the primary objective of the appointed factory doctor service-namely, the care of young people. The concept of care in this sense is something different from care in the past. It is a matter of urgency to investigate the extent and nature of need in the context of a changing role for medicine and the stress of modern life.

The Seebohm report ${ }^{1}$ particularly recommended that medical and social services for the less privileged young people should be as good as those for the more privileged at college and universities. It is a curious action of the Government to implement the Seebohm report and introduce such a retrograde new Bill. It would appear that the Department of Employment and Productivity has an almost indecent desire to get an occupational health service divorced from the National Health Service and are indifferent to the problems of young people in the transition from school to work. Can nothing be done to delay decision.-I am, etc.,

Farnham Royal, Bucks

M. E. M. HERFORD

1 Local Authority and Allied Personal Social Services. Report, Cmnd. 3703. London,
H.M.S.O., 1968. 